\title{
Seeding Western Wheatgrass with Increasing Rates of Perennial Ryegrass or Smooth Brome in Waterways ${ }^{1}$
}

\section{J. L. LAUNCHBAUGH}

Pasture Management Specialist, Fort Hays Branch, Kansas Agricultural Experiment Station, Hays, Kansas.

\section{Highlight}

Western wheatgrass was planted at $8 \mathrm{lbs}$. per acre with increasing rates of perennial ryegrass and smooth brome in a new waterway. Perennial ryegrass increased until the second or third season, then was replaced by western wheatgrass. Smooth brome increased and dominated all plots. It seems advisable to use short-lived, unadapted plants such as perennial ryegrass as companion species to western wheatgrass.

Western wheatgrass (Agropyron smithii Rydb.) occurs as a major dominant in many western Kansas waterways. Atkins (1957) reported that although slow to become established, western wheatgrass eventually produces a dense, thrifty sod more suitable for waterway protection than many tame grasses. Tame grasses establish quickly but often require intensive management to maintain adequate cover (Cooper, 1957).

Since rapid coverage and lasting soil protection are both desirable in establishing grassed waterways, planting a tame species with western wheatgrass in the proper combination was postulated as a means of obtaining both objectives i.e. rapid initial coverage by a tame species and in time, permanent coverage by western wheatgrass through plant succession. This study compares plantings of western wheatgrass seeded at a constant rate with increasing rates of each of two tame grasses having different growth habits, namely perennial ryegrass (Lolium perenne L.) -a bunchgrass, and

1 Contribution No. 189, Fort Hays Branch, Kansas Agricultural Experiment Station, Hays, Kansas. smooth brome (Bromus inermis Leyss.)-a sod forming species. Specific objectives were to determine the effects of tame-species planting rates on first-year seedling numbers, and to record foliage cover and species composition changes in relation to initial stands under waterway conditions. Results of planting in 1959 and cover changes during five successive growing seasons are reported and discussed.

\section{Experimental Area and Methods}

Luebs (1962) described the experimental area on the Fort Hays (Kansas) Branch Experiment Station at Hays. The soil is silty clay loam, representative of many upland areas in north-central Kansas. The site had a cropping history of wheat, sorghum, and summer fallow for nearly 50 years previous to this experiment. Native vegetation on similar soils consists of buffalograss (Buchlö̈ dactyloides [Nutt.] Engelm.), blue grama (Bouteloua gracilis [H.B.K.] Lag. $x$ Steud.), and western wheatgrass in varying mixtures. Species composition is influenced to a large extent by intensity of livestock grazing (Launchbaugh, 1957).

Mean annual precipitation for the area is 22.94 inches, with an average of 17.74 inches during the growing period, April to October. There were significant moisture deficits the first five months of 1962 and from October, 1962, to July, 1963, otherwise drought periods were infrequent and of relatively short duration, especially during months of most active plant growth. Summer temperatures generally were slightly lower than the mean, while winter temperatures frequently were 10 to 15 degrees below long-time means.

A waterway was shaped and berms constructed during the winter of 1957-58. Although the site possessed natural drainage, it was necessary to move several inches of topsoil from the center to the berms to create a uniform channel. Thus in shaping, site qualities of the channel were altered in relation to the side slopes where topsoil was deposited. Ellis forage sorghum was sown thickly on the waterway in July, 1958. Average production was approximately 4,000 pounds of dry matter per acre, which was left undisturbed for seedbed cover. Grass was planted April 15 , 1959, using a four-row plot drill equipped with double-disk planters, packers, and V-belt seed conveyors to distribute known quantities of seed evenly in a prescribed length of row. Seed placement was $1 / 2$ to $3 / 4$ inch deep in one-foot row spacings. The experiment consisted of two whole plots (in which the seeding rate of western wheatgrass was constant at 8 pounds per acre) and eight subplots each for perennial ryegrass and smooth brome at increasing rates from 0 to 24 pounds per acre in combination with western wheatgrass. Planting rates in pounds per acre and in terms of calculated viable seeds (PLS) per foot of row are shown in Table 1. Subplots were 12 rows, 16 feet long. The planting mixtures were replicated in three randomized blocks for each whole plot. Two replications were located on the sloping sides of the waterway where soil was deposited and the third in the channel area where topsoil was removed. Planting was done at right angles to the longitudinal axis of the waterway.

Sampling included seedling counts at the end of the first growing season in 13-foot seg- 
Table 1. Rates of companion species planted with western wheatgrass seeded at a constant rate of 8 pounds per acre or approximately 12 PLS $^{1}$ per foot of row.

\begin{tabular}{ccc}
\hline \multirow{2}{*}{$\begin{array}{c}\text { Planting rates } \\
\text { of companion } \\
\text { species }\end{array}$} & \multicolumn{2}{c}{$\begin{array}{c}\text { Approximate PLS } \\
\text { per foot of row }\end{array}$} \\
\cline { 2 - 3 } & $\begin{array}{c}\text { Perennial } \\
\text { ryegrass }\end{array}$ & $\begin{array}{c}\text { Smooth } \\
\text { brome }\end{array}$ \\
\hline (lb./A.) & -- (number) & - \\
0 & 0 & 0 \\
$1 / 2$ & 2 & 1 \\
1 & 4 & 2 \\
2 & 8 & 4 \\
4 & 16 & 8 \\
8 & 32 & 16 \\
16 & 64 & 32 \\
24 & 96 & 48 \\
\hline
\end{tabular}

1Pure live seed estimated from purity and germination analyses.

ments of each row, and foliage cover estimates by species based on the means of six independent ocular estimates per subplot by two observers each fall for five seasons.

\section{Results}

First-year Seedling Numbers. -Seedlings of all species began to appear by late April, 1959, and continued to emerge during May. Total numbers on September 1, 1959, are shown in Table 2. Initial stands of western wheatgrass were highly variable and were influenced significantly only by the highest seeding rates of perennial ryegrass and smooth brome. Individual rows con- tained from one to 10 western wheatgrass seedlings per 13 feet, in most instances with no apparent relationship to the abundance of companion seedlings. Both companion grasses produced seedling numbers in linear proportion to the planting rates, with highly significant positive correlation coefficients of over .90. Average number of viable seeds needed to obtain one seedling by species follows: perennial ryegrass, 17; smooth brome, 21; and western wheatgrass, 56 . Considerable differential in the ability of the various species to emerge and persist under similar field conditions is indicated, or questionable relationships exist between seed quality analyses and responses to field planting conditions. In addition to producing more seedlings per unit of viable seed, the tame species produced considerably more uniform stands than did western wheatgrass.

Foliage Cover and Species Composition.-All species increased by tillering. Figure 1 shows the changes in foliage cover during five successive growing seasons. Important differences in total cover were manifest during the first and second seasons when plots containing western wheatgrass alone and the lower populations of tame species had much less cov-

Table 2. First-year seedlings resulting from planting western wheatgrass at a constant rate in separate mixtures with two companion species at various rates.

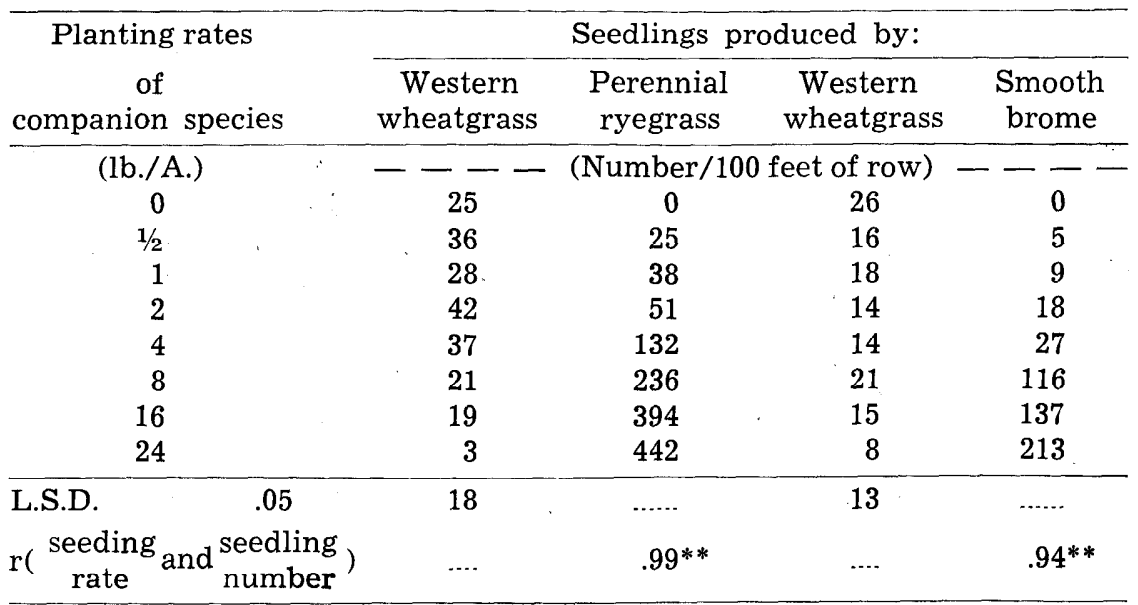

erage than those with the higher densities of perennial ryegrass or smooth brome. By the end of the third season, coverage was nearly the same regardless of companion species seeding rate. Thereafter, total foliage cover apparently was influenced by growing conditions rather than original seedling numbers.

Species composition changes during the five years were influenced by companion species and initial proportion of seedlings. Western wheatgrass was relatively very low in amount at the end of the first growing season, especially at the higher seeding rates of perennial ryegrass and smooth brome. However, the wheatgrass increased consistently at the expense of perennial ryegrass and was the only species present after four growing seasons. Western wheatgrass associated with various amounts of smooth brome, on the other hand, increased in percentage to the third and fourth growing seasons then decreased in relative coverage. At the end of the fifth growing season, smooth brome dominated all plots where it occurred in the planting mixture except those at the half pound per acre rate. There it nearly equalled western wheatgrass.

\section{Discussion}

Apparently the tame grasses used may be included with western wheatgrass over a wide range of planting rates without having appreciable effect on first-year seedling numbers of western wheatgrass. This may be true, however, only if western wheatgrass and the companion species emerge simultaneously, as in these trials. Studies of competition between reseeded annual ryegrass (Lolium multiflorum Lam.) and several perennial grasses, reported by Schultz and Biswell (1952), showed that when annual ryegrass emerged from three to seven weeks before the perennials, there were 

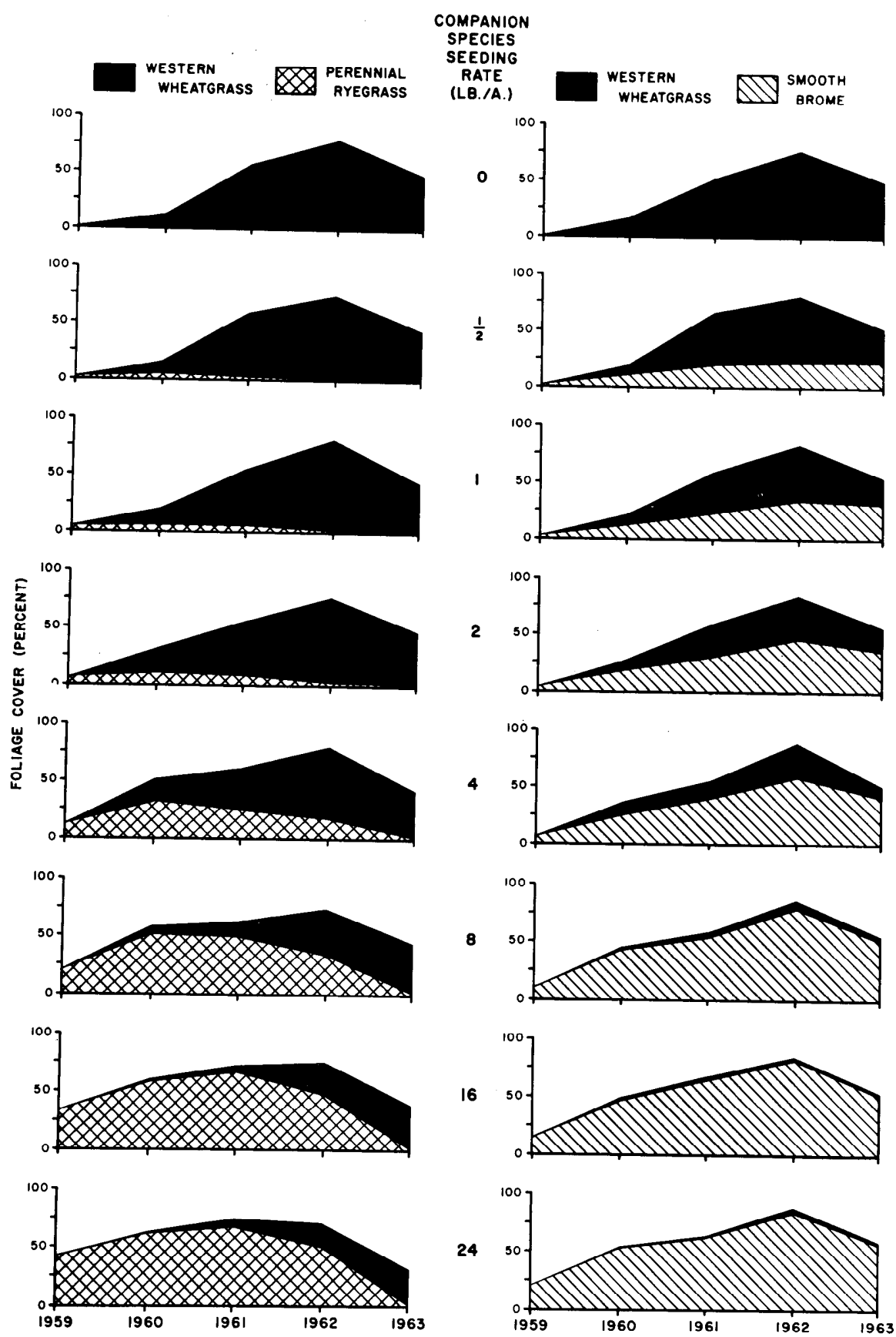

Figure 1. Annual chang:s in foliags cover and composition of western wheatgrass alone and in sarate combinations with various planting rates of perennial ryegrass and smooth brome.

significant reductions in number and development of associated perennial grass plants. When alrcady well established, annual ryegrass crowded out a large number of perennial grass seedlings throughout the growing season and retarded development of those that survived.

Rapid spread of persistent plants is desirable in all newly
Studies by McWilliams (1955) have shown that yields from light seeding rates are lower in new stands, but increase and become equal to or greater than yields from heavier seeding rates as the stands age. Presumably narrower row spacing would have compensated somewhat for paucity of stand within the row and resulted in more comparable total cover by the end of the second season regardless of initial stand. However, it appears that first-year stands of western wheatgrass, because of sparse populations and tillering, seldom would offer erosion protection comparable to mixtures with species that tiller profusely and are leafier. Older stands of western wheatgrass, unless grazed or mowed and raked cleanly, contain accumulated old plant residue in addition to current growth and appear to provide effective erosion protection under waterway conditions.

After various species are established, composition changes result from plant competition. The contrasting trends of succession noted in this study may have been due primarily to the competitive advantage of a rhizomatous species such as western wheatgrass over a slowly spreading bunchgrass in one case and the lack of such an advantage when two rhizomatous species were involved. Original plants of perennial ryegrass made only modest peripheral increases in basal coverage. Rows were evident in plots containing perennial ryegrass throughout the experiment. Western wheatgrass occupied the intervening row spaces and replaced perennial ryegrass as it died. In contrast, smooth brome tillered profusely and occupied the bare areas as readily or more so than western wheatgrass. Rows were not evident after the second growing season. The relatively dry springs of both the fourth and fifth growing seasons did not favor cool-season grasses. Perennial 
ryegrass may have been more adversely affected by drought than either western wheatgrass or smooth brome. The fifth-season drought was about equally detrimental to both western wheatgrass and smooth brome.

The aggressiveness of smooth brome agrees with observations by Atkins (1957), that on waterways where soil fertility and permeability were favorable for the growth of tame grasses, increase in native grasses was slow in competition with smooth brome. Cooper (1957) stated that tame grasses such as smooth brome, in contrast to native species, eventually need intensive management including fertilization to maintain adequate cover for waterway requirements. A longer period of observation is necessary to determine the comparative staying qualities of western wheatgrass and smooth brome under the condition of this study.

These plantings, characteristic of newly reseeded areas, had varying densities of first-season annual weeds including kochia (Kochia scoparia [L.] Schrad.), pigweed (Amaranthus spp.), and several minor species. Weed densities were not high enough to smother the grass seedlings nor to influence their development significantly. If weed populations do not prevent the establishment of a desirable grass cover, their presence in the early stages may serve some purpose by adding to the total vegetation cover. Weeds persisted during the second year in plots with open grass cover, but were essentially absent from all plots thereafter.

Significant differences existed between replications in initial grass seedling numbers and subsequent total vegetation cover. The plots were located so that each slope below the berms constituted two replications and the channel area, a third. In each instance, seedling numbers and foliage cover estimates were lower in the center replication than in adjacent locations. Topsoil transfer during waterway construction and consequent alteration of site potential probably accounted for the differences observed.

\section{Summary and Conclusions}

Western wheatgrass was planted at a constant rate in separate combinations with increasing rates of perennial ryegrass and smooth brome in a newly shaped waterway at Hays, Kansas. Data on first-year stands and plant cover changes during five successive growing seasons are presented.

Western wheatgrass seedling numbers varied but were lowered significantly only by the highest rates and seedling densities of both companion species. Seedling numbers of companion grasses were in linear proportion to the number of viable seeds planted.

Foliage cover of western wheatgrass alone and with the lower seeding rates of tame grasses was less until the third growing season compared with plots containing higher seeding rates of introduced grasses. Total foliage cover was not influenced by original planting rates after the third growing season.

Two trends in plant succession were observed. Perennial ryegrass increased in foliage cover until the second or third season, then began to decline and was replaced completely by western wheatgrass before the end of the fifth growing season. Smooth brome, in contrast, increased rapidly and dominated the plots at all rates except the lowest by the end of the fifth growing season.

In view of these findings it appears that high initial coverage may be achieved by including tame species at high seeding rates with western wheatgrass. For plant succession to culminate in western wheatgrass dominance within a few years, it seems advisable to use a shortlived, unadapted species such as perennial ryegrass as the companion species, otherwise adapted, more aggressive tame species may delay or prevent the desired trend in plant succession.

\section{LITERATURE CITED}

AtKins, M. D. 1957. Permanent waterways. Crops and Soils $10(2)$ : 14-15.

Cooper, H. W. 1957. Some plant materials and improved techniques used in soil and water conservation in the Great Plains. Jour. Soil and Water Conserv. 12: 163-168.

Launchbaugh, J. L. 1957. The effect of stocking rate on cattle gains and on native shortgrass vegetation in west-central Kansas. Kan. Agr. Exp. Sta. Bul. 394. 29 pp.

LUEBS, R. E. 1962. Investigations of cropping systems, tillage methods, and cultural practices for dryland farming at the Fort Hays (Kansas) Branch Experiment Station. Kan. Agr. Exp. Sta. Bul. 449. 114 pp.

McWilliams, Jesse L. 1955. Effects of some cultural practices on grass production at Mandan, North $\mathrm{Da}$ kota. U. S. Dept. Agr. Tech. Bul. 1097. $28 \mathrm{pp}$.

Schultz, A. M. ANd H. H. Biswell. 1952. Competition between grasses reseeded on burned brushlands in California. Jour. Range Mangt. 5: 338-345. 